\title{
The impact of financial participation on workers' compensation
}

\author{
Martyn Andrews · Lutz Bellmann • Thorsten Schank • Richard Upward
}

Received: 22 December 2009 / Accepted: 21 May 2010 / Published online: 25 June 2010

(C) Institut für Arbeitsmarkt- und Berufsforschung 2010

\begin{abstract}
We investigate the impact of financial participation (profit-sharing and share ownership) on workers' total compensation. Some workers' representatives have argued against the introduction of profit-sharing because they fear that profit-sharing would be a way for firms to reduce the marginal cost of hiring workers, while at the same time transferring some of the risk of variable profits from firms to workers. We find that workers in plants which operate financial participation schemes earn significantly more: $25 \%$ in the case of profit-sharing and $18 \%$ in the case of share ownership. However, econometric models which deal with selection by plants and workers into profit-sharing schemes suggest that the effect on total compensation is much smaller: between $4 \%$ (from a difference-in-differences regression) and $2.5 \%$ (from a comparison of matched pairs). We find no evidence that high-skilled white-collar workers benefit more strongly from profit-sharing schemes.
\end{abstract}

Keywords Wages · Employees' financial participation . DiD matching

\section{Andrews}

University of Manchester,

Manchester, UK

L. Bellmann (ब)

Institut für Arbeitsmarkt- und Berufsforschung,

Regensburger Straße 104, 90478 Nuremberg, Germany

e-mail: lutz.bellmann@iab.de

L. Bellmann · T. Schank

Friedrich-Alexander Universität Erlangen-Nürnberg,

Erlangen, Germany

R. Upward

University of Nottingham,

Nottingham, UK
JEL classification J33 · C23

\section{Der Einfluss von finanzieller Mitarbeiterbeteiligung auf die Entlohnung der Arbeitnehmer}

Zusammenfassung Dieser Beitrag untersucht den Einfluss von finanzieller Mitarbeiterbeteiligung (Gewinn- und Kapitalbeteiligung) auf die Entlohnung. Arbeitnehmervertreter sprechen sich oft gegen die Einführung von Gewinnbeteiligungssystemen aus, da sie befürchten, dass auf diesem Weg die Unternehmen zwar die Einstellungskosten senken, gleichzeitig aber auch einen Teil des Risikos variierender Gewinne auf die Beschäftigten verlagern. Wir finden, dass Beschäftigte in Betrieben mit Gewinnbeteiligung $25 \%$ und in Betrieben mit Kapitalbeteiligung $18 \%$ mehr verdienen als Beschäftigte in Betrieben ohne Mitarbeiterbeteiligung. Allerdings wird der Einfluss bedeutend kleiner, nachdem für die Selbstselektion von Betrieben in solche Entlohnungsformen kontrolliert wird und beträgt nur noch zwischen 4,1 (Differenz-in-DifferenzenSchätzung) und 2,5\% (Vergleich von gematchten Paaren). Wir finden keine Evidenz dafür, dass hochqualifizierte Angestellte stärker von einer Mitarbeiterbeteiligung profi tieren.

\section{Introduction}

The financial participation of employees in their firm, in the form of profit-sharing or share ownership, continues to increase across almost all European countries, albeit from a low level in many of them. The fourth European Working Conditions Survey (Welz and Macias 2007) suggests that, in 2005, around $10 \%$ of European workers participate 
in profit-sharing schemes, and around $2 \%$ in share ownership schemes. To a greater or lesser extent these schemes have been encouraged by European governments via the use of tax incentives and legislation. The second "Pepper Report" (Commission of the European Communities 1996), argued that increased use of profit-sharing would encourage greater productivity, wage flexibility, employment and employee involvement, and called on member states to promote the greater use of financial participation by employees.

Although the concept of profit-sharing has existed for at least 150 years in Germany (Von Thünen 1850), this form of remuneration is still not widespread. The Property Development Act of 1984 (amended in 1994) was the first legislation which specifically encouraged the participation of employees in the assets of their firms (Carstensen et al. 1995). Incentives for profit-sharing and share ownership include limited cash subsidies and some exemptions from tax and social security payments. Incentives for profit-sharing and share ownership are interrelated, and so we expect to find firms offering both schemes simultaneously. Legally, profit-sharing in firms can either be based on individual contracts between firms and workers or on contracts between the works council and the firm.

The academic debate on financial participation initially focussed on a series of papers by Weitzman (e.g. Weitzman 1984, 1987), which suggested that profit-sharing could lower the marginal cost of hiring workers and hence permanently increase the level of employment. However, a key finding of the empirical literature on profit-sharing is that the introduction of such schemes is not generally associated with reductions in the basic wage. ${ }^{1}$ This suggests that the widespread introduction of profit-sharing schemes would not have the positive employment effects advocated by Weitzman. A second finding of the empirical literature is that the introduction of profit schemes is associated with higher productivity. Prendergast (1999) implicitly suggests that these two facts may be linked. If the introduction of profit-sharing leads to higher total compensation for workers, this might explain higher productivity, either because of worker selection or efficiency wage mechanisms.

In contrast, some workers' representatives have argued against the introduction of profit-sharing because they fear precisely what Weitzman hoped for: that profit-sharing would be a way for firms to reduce the marginal cost of hiring workers, while at the same time transferring some of the risk of variable profits from firms to workers. The European Foundation argues that employee representatives are more likely to accept the introduction of financial sharing if there is protection of workers from "unreasonable

\footnotetext{
${ }^{1}$ Indeed, Welz and Macias (2007) argue that “. . . in practice, most schemes are devised in such a way that participants only benefit: they are not exposed to financial risk either individually or collectively".
}

risk" and there is a prohibition of wage substitution (Welz and Macias 2007).

In this paper we provide detailed evidence on the relationship between the use of financial participation schemes and total worker compensation using a large panel of German plants linked to data on the workers in those plants. We are able to control for a wide range of worker and plant characteristics which might affect the use of financial participation schemes as well as total compensation. The use of linked worker-plant panel data also allows us to control for unobserved plant and worker effects on compensation by comparing plants which introduce profit-sharing with similar plants who do not. Thus, we provide new evidence on how much workers gain from financial participation in their firms.

We can also examine whether the introduction of financial participation has an effect on the selection of workers in and out of the plant. ${ }^{2}$ In theory, workers' preferences for increased risk (or plants' preferences for workers with certain characteristics) could lead to changes in the composition of the workforce. By comparing workers who remain in the plant with those who join or leave we can effectively control for this when calculating the effect on workers' compensation.

The use of linked worker-plant data also allows us to examine whether financial participation has effects on the distribution of compensation across different types of worker. Lemieux et al. (2009) have recently provided evidence that the increasing use of performance pay in the US has resulted in greater wage inequality amongst workers who receive performance pay. In this paper we examine whether the introduction of profit-related pay has differential affects on workers' compensation according to their sex, age, tenure and occupation.

We begin in Sect. 2 by briefly reviewing the evidence on financial participation and worker compensation. The data we use and some basic descriptives are presented in Sect. 3 . Our methods are described in Sect. 4 and the results are presented in Sect. 5. Section 6 concludes.

\section{Literature}

The first wave of papers followed from Weitzman's (1984) book and accompanying articles, such as Weitzman (1987). Three key questions emerge from the literature, only the first of which directly relates to Weitzman's hypothesis.

First, does profit-sharing reduce the base wage? If the introduction of profit-sharing is not accompanied by a reduc-

\footnotetext{
${ }^{2}$ Bellmann and Möller (2010), using the same plant-level data, find a significant positive effect on hirings and a significant negative effect on layoffs, although results obtained from matching estimators are not significant.
} 
tion in the base wage, or the marginal cost of labour, then we would not expect to observe increases in the demand for labour. The empirical consensus is that the introduction of profit-sharing does not reduce the base wage. For example, Wadhwani and Wall (1990) and Bhargava and Jenkinson (1995) (using firm-level data) and Hart and Hübler (1991) (using German household survey data) find no evidence that profit-sharing reduces the base wage. In some cases, in fact, profit-sharing is associated with increases in the base wage. These findings are more compatible with rent-sharing and efficiency wage theories. One exception to these findings is Estrin and Wilson (1986), who found that the introduction of profit-sharing reduced total compensation while at the same time increasing employment. More recently, Buchele et al. (2009, p. 13) note some recent high-profile examples of US workers who have accepted lower wages in return for ownership shares and stock options. However, their own empirical evidence confirms the stylised fact that there is a positive relationship between total compensation and financial participation. Finally, Cuñat and Guadalupe (2009) show that the introduction of more incentive pay increases within-firm pay differentials for executives, and thus potentially has an impact on wage inequality.

Second, there is a large body of empirical literature which has established as a stylised fact that profit-sharing firms have higher productivity than similar non-profitsharing firms. FitzRoy and Kraft (1987) is an early example using a small cross-section of West German engineering firms, who find a positive relationship between total factor productivity and profit-sharing. Cable and Wilson (1989) estimate production functions for a small sample of UK engineering firms. The estimated models predict output differentials of between 3-8\% between profit-sharing and other firms. However, they argue that the productivity effects of profit-sharing are likely to require other aspects of organisational design. Kruse $(1992,1993)$ finds that profit-sharing increases productivity significantly in a sample of 3,000 US firms. Knez and Simester (2001) analyse the effect of the introduction of a firm-wide incentive scheme in a large US company, and show that it significantly increased worker performance. Jones and Kato (1995) use firm-level panel data from Japan to show that firms which introduce employee stock ownership plans experience a 4-5\% increase in productivity, and that it takes a few years for this effect to be felt. Doucouliagos (1995) provides a meta-analysis of 43 studies on the relationship between various types of participatory arrangements and productivity, and finds consistent positive relationships with profit-sharing and share ownership, although these effects are stronger in labor-managed firms.

Prendergast (1999) is somewhat skeptical as to whether these results are evidence of a causal relationship between profit-sharing and productivity. First of all, the correlation might just reflect the selection of more productive firms into profit-sharing schemes. But many of the studies use within-firm changes to deal with this problem, and the results generally hold up. Some authors have explicitly considered selection into modes of payment. FitzRoy and Kraft (1995) use the same data as in FitzRoy and Kraft (1987) but consider selection, since firms are assumed to choose the incentive structure which maximises profits. Kraft and Ugarković (2006), using the same data as we do in this paper, use propensity score matching to compare firms which start profit-sharing with observably equivalent firms which do not.

A second problem raised by Prendergast (1999) with this literature is that the theory considers the effect of incentives holding utility constant. But, as noted, the base wage does not fall with profit-sharing, and so total compensation will generally increase. Prendergast therefore wonders "Could the empirical results simply reflect the effect of giving workers more money, and not the effect of team production?" (Prendergast 1999, p. 43). He suggests instead that higher compensation might induce positive selection of workers into the firm, or it might have efficiency wage effects.

The third main strand of the literature relates to this question, and asks how profit-sharing can improve productivity in the face of the well-known free-rider problem, often referred to as the " $1 / n$ " problem. One solution to this problem is the use of peer-monitoring or peer-pressure. Knez and Simester (2001) argue that the positive effects of the incentive scheme they studied were achieved because of the organisation of employees into autonomous work-groups which allowed for mutual monitoring of performance.

One might expect that team-based performance measures would encourage the less productive, since they can freeride. But Weiss (1987) finds an inverse U-shaped relationship between worker turnover and prior productivity. The most able and the least able are more likely to leave the company. Wilson et al. (1990) and Wilson and Peel (1991) use a small sample of UK engineering firms and examine how quit rates and absenteeism vary as a function of firm characteristics, including unionism and profit-sharing. They find that firms with financial participation schemes have significantly lower absenteeism and quit rates.

The most recent evidence comes from an NBER project: see, for example Freeman (2008), Blasi et al. (2008) and Kruse et al. (2008). Freeman (2008) concentrates on the idea that worker co-monitoring can get around the free-rider problem. Blasi et al. (2008) examine whether the mechanism by which profit-sharing increases worker productivity is via gift exchange. They interact a measure of pay with an index of shared capitalism. Kruse et al. (2008) find that "greater involvement in the programs (shared compensation schemes) is generally linked to greater participation in decisions, higher quality supervision and treatment of 
employees, more training, higher pay and benefits, greater job security, and higher job satisfaction".

We make a number of contributions to this literature. Instead of examining the base wage, we ask whether workers are better off overall if they work in plants which introduce financial participation in the form of profit-sharing or share ownership. We do this by measuring total compensation. We use both difference-in-differences and matching to control for non-random selection of plants into financial participation schemes. Because we use linked worker-plant data we are also able to examine the selection effects of financial participation, and to control for this selection effect in determining any change in average earnings. Finally, the use of linked worker-plant data allows us to examine whether the impact of profit-sharing on earnings varies across different types of plant and different types of worker. For example, Cuñat and Guadalupe (2009) suggest that incentive pay increases pay differentials within firms. By examining the impact of financial participation on different groups of workers we can examine this issue.

\section{Data and institutional background}

There are two data sources. The first is the Institut für Arbeitsmarkt- und Berufsforschung (IAB) Establishment Panel, an annual survey of approximately 16,000 plants located across the whole of Germany. It covers $1 \%$ of all plants and $7 \%$ of all employment in Germany, and is therefore a sample weighted toward larger plants. ${ }^{3}$ The sample covers all industries. Information is obtained by personal interviews with plant managers, and comprises about 80 questions per year, giving us information on, for example, total employment, bargaining arrangements, total sales, ownership, investment, wage bill, location, industry, profit level and nationality of ownership. We restrict the analysis to plants in the private sector. A detailed description of the IAB Establishment Panel can be found in Fischer et al. (2009).

The question on profit-sharing/share ownership was asked in 2000, 2001, 2005 and 2007. ${ }^{4}$ The question asked is as follows: "Are there, in your plant, additional financial

\footnotetext{
${ }^{3}$ Weights to ensure that the sample is representative are calculated by comparing the sample of establishments with the population of establishments in the same Federal state, size and industry cell. The population of plants is obtained from a Federal Employment Agency establishment database. The weighting procedure is described in more detail in Fischer et al. (2009). Note that we compare the weighted and unweighted responses when describing the basic sample statistics, but focus on unweighted data in the regression analysis.

${ }^{4}$ A question was also asked in 1998, but it was part of a multi-choice question which asked about various diverse aspects of employment policy. There was also a smaller change in the question between 2000 and 2001; see the discussion following Table 1.
}

incentives for employees in the form of profit- or capitalsharing?"5 Respondents could tick "Yes" or "No" for both types of scheme, together with the proportion of workers covered by the scheme.

The second source of data is the employment statistics register of the German Federal Office of Labour (Beschäftigtenstatistik), which covers all workers or trainees registered by the social insurance system. The register covers about $80 \%$ of workers in Western Germany and about $85 \%$ in Eastern Germany. However, almost all workers in the private sector are covered by the social insurance system, so the data we use covers nearly $100 \%$ of workers. Information on workers includes basic demographics, start and end dates of employment spells, occupation and industry, earnings, qualifications (school and post-school), and a plant identification number. A detailed description of the employment data can be found in Bender et al. (2000).

For each worker we observe the average daily total compensation, $y_{i t}$, for each calendar year. We only use observations where the information on compensation covers the whole calendar year. This is because information on part-year spells might not include bonuses which are paid at a particular point in the year (typically at the end of the year). We use information only on full-time workers ${ }^{6}$ because, for part-time workers, changes in $y_{i t}$ are more likely to reflect changes in hours of work, which we do not observe.

By using the plant identification number we can associate each worker with a plant in the panel. Because the employment register is spell-based (one record for each employment spell), the combined data is potentially complex. To simplify, we select all workers in the employment register who are employed by the surveyed plants on June 30th each year, for 2000, 2001, 2005 and 2007. This yields an unbalanced annual panel of workers together with detailed information on the plants in which they work. It is then straightforward to aggregate the data to plant-level after recording summary information on the workers in those plants.

After removing plants which are not in the private sector, and which have missing values on the variables relating to profit-sharing or employee share ownership, we have a sample of over 10,000 plants in each year. Table 1 reports the sample size together with the proportion of plants operating profit-sharing or employee share ownership. The incidence of profit-sharing and share ownership has been growing in our data. However, most of this increase occurs between 2000 and 2001. As noted, the question became more precise from 2001 onwards, and it seems possible that this is respon-

\footnotetext{
${ }^{5}$ In the rest of the paper we refer to this as employee share ownership.

6 "Full-time" is reported by the employer; we do not know exactly how many hours this definition corresponds to.
} 
Table 1 Incidence of financial participation in the IAB establishment panel

\begin{tabular}{lccccc}
\hline & $\begin{array}{c}\text { Number of } \\
\text { plants }\end{array}$ & Any sharing & $\begin{array}{c}\text { Unweighted } \\
\text { Profit- } \\
\text { sharing }\end{array}$ & $\begin{array}{c}\text { Share } \\
\text { ownership }\end{array}$ & $\begin{array}{c}\text { Any sharing } \\
\text { Share } \\
\text { ownership } \\
\text { Profit- } \\
\text { sharing }\end{array}$ \\
\hline 2000 & 10,874 & 0.143 & 0.119 & 0.044 & 0.062 \\
2001 & 11,423 & 0.187 & 0.174 & 0.046 & 0.069 \\
2005 & 12,946 & 0.193 & 0.181 & 0.037 & 0.095 \\
\hline
\end{tabular}

${ }^{a}$ Weights used are those described in Fischer et al. (2009, Sect. 4.2).

Table 2 Incidence of financial participation by plant characteristics

\begin{tabular}{|c|c|c|c|}
\hline & Any sharing & Profit-sharing & Share ownership \\
\hline \multicolumn{4}{|l|}{ Number of employees } \\
\hline$<5$ & 0.056 & 0.051 & 0.015 \\
\hline $5-9$ & 0.088 & 0.079 & 0.019 \\
\hline $10-19$ & 0.132 & 0.122 & 0.025 \\
\hline $20-49$ & 0.193 & 0.180 & 0.038 \\
\hline $50-99$ & 0.252 & 0.234 & 0.048 \\
\hline $100-199$ & 0.294 & 0.273 & 0.058 \\
\hline $200-499$ & 0.350 & 0.325 & 0.075 \\
\hline $500-999$ & 0.433 & 0.398 & 0.111 \\
\hline$\geq 1000$ & 0.591 & 0.534 & 0.247 \\
\hline \multicolumn{4}{|l|}{ Bargaining arrangements } \\
\hline No collective bargaining & 0.140 & 0.131 & 0.027 \\
\hline Bargaining at the plant level & 0.220 & 0.202 & 0.054 \\
\hline Bargaining at the industry level & 0.267 & 0.242 & 0.070 \\
\hline \multicolumn{4}{|l|}{ Works councils } \\
\hline No works council in the plant & 0.118 & 0.110 & 0.022 \\
\hline Works council in the plant & 0.352 & 0.323 & 0.092 \\
\hline \multicolumn{4}{|l|}{ Location of plant } \\
\hline Western Germany & 0.206 & 0.191 & 0.047 \\
\hline Eastern Germany & 0.139 & 0.127 & 0.031 \\
\hline \multicolumn{4}{|l|}{ Industry } \\
\hline Agriculture & 0.101 & 0.085 & 0.039 \\
\hline Mining, energy & 0.276 & 0.247 & 0.078 \\
\hline Food & 0.127 & 0.114 & 0.028 \\
\hline Consumer goods & 0.152 & 0.136 & 0.029 \\
\hline Producer goods & 0.203 & 0.186 & 0.048 \\
\hline Investment goods & 0.272 & 0.254 & 0.059 \\
\hline Construction & 0.097 & 0.087 & 0.027 \\
\hline Trade & 0.178 & 0.166 & 0.034 \\
\hline Transport, communication & 0.157 & 0.145 & 0.035 \\
\hline Banks, insurance & 0.466 & 0.406 & 0.165 \\
\hline Catering & 0.090 & 0.086 & 0.014 \\
\hline Education & 0.176 & 0.167 & 0.028 \\
\hline Health service & 0.091 & 0.085 & 0.013 \\
\hline Services for companies & 0.220 & 0.208 & 0.054 \\
\hline Other services & 0.127 & 0.120 & 0.018 \\
\hline
\end{tabular}

Note: Pooled sample, 2000, 2001, 2005 and 2007.

Weights used are those described in Fischer et al. (2009, Sect. 4.2). sible for the apparent increase in the proportion of plants reporting sharing arrangements. ${ }^{7}$ This proportion adopting

\footnotetext{
${ }^{7}$ We therefore ensure that in our empirical work we do not rely on "changers" between 2000 and 2001 .
}

either profit-sharing or employee share ownership is much lower once we use the sampling weights, reflecting in part the fact that larger plants (who are oversampled) are more likely to adopt such schemes.

Some more detailed characteristics of the incidence of sharing arrangements are shown in Table 2. The table shows 
Fig. 1 Proportion of plants with profit-sharing or employee share ownership by industry

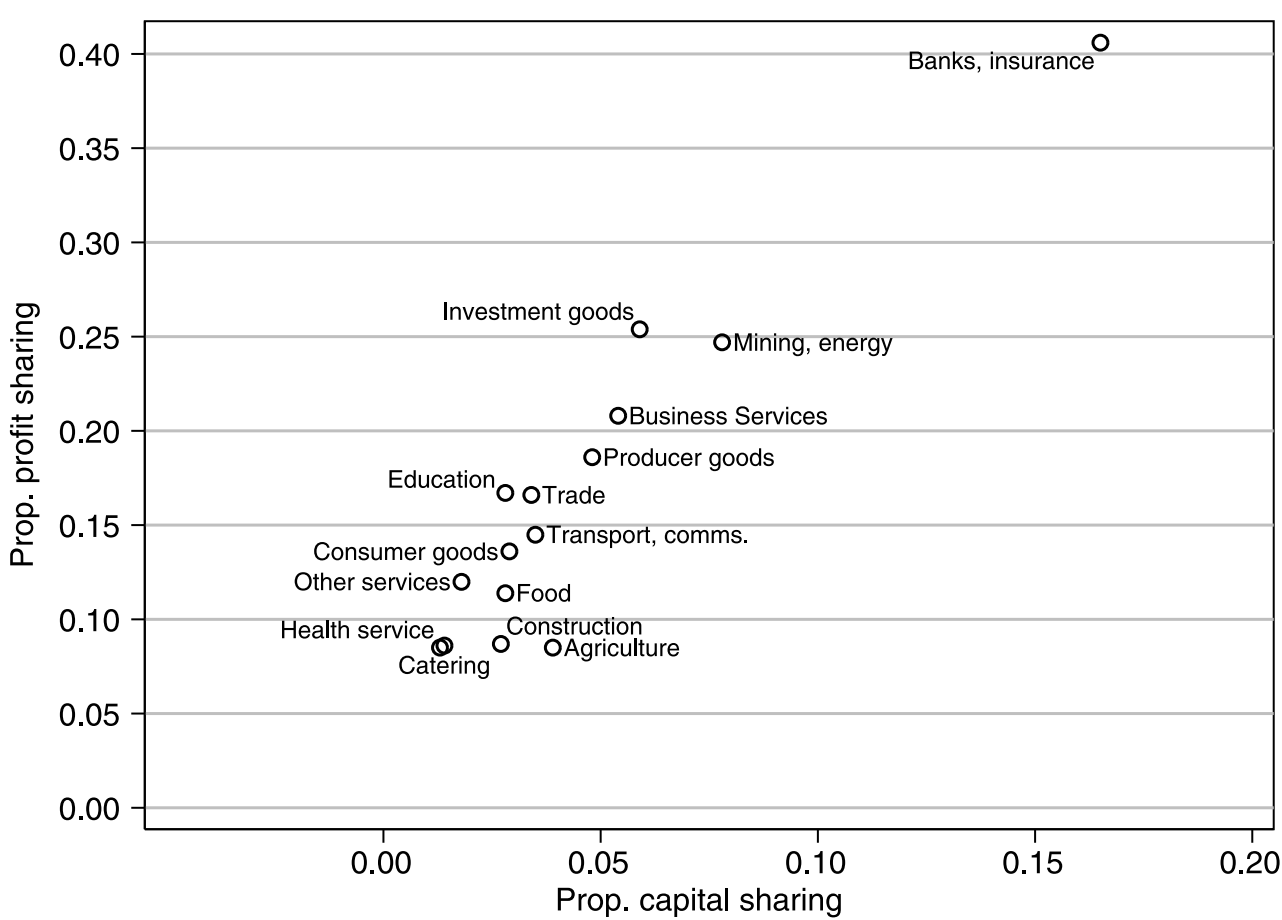

Table 3 Incidence of financial participation amongst workers in the IAB establishment panel

\begin{tabular}{lcccc}
\hline & $\begin{array}{c}\text { Number of } \\
\text { plants }\end{array}$ & $\begin{array}{c}\text { Number of } \\
\text { workers }\end{array}$ & $\begin{array}{c}\text { Profit- } \\
\text { sharing }^{\mathrm{b}}\end{array}$ & $\begin{array}{c}\text { Share } \\
\text { ownership }^{\mathrm{b}}\end{array}$ \\
\hline 2000 & 10,874 & $1,677,995$ & 0.087 & 0.045 \\
2001 & 11,423 & $1,778,496$ & 0.132 & 0.050 \\
2005 & 12,946 & $1,855,923$ & 0.147 & 0.033 \\
$2007^{\mathrm{a}}$ & 12,957 & $1,610,415$ & - & - \\
\hline
\end{tabular}

${ }^{a}$ Share of workers covered not available in 2007.

${ }^{\mathrm{b}}$ Weighted by sampling weights.

that larger plants, plants in Western Germany and plants in banking and finance are far more likely to have sharing arrangements.

Figure 1 shows the pattern of sharing by industry more clearly. Industries which use profit-sharing intensively are also much more likely to have employee share ownership schemes. It is striking that the least labour intensive industries (mining and energy, banking and finance, wholesale and retail trade, investment goods, producer goods) are much more likely to have financial participation.

What proportion of workers in a plant are covered by profit-sharing or employee share ownership schemes? Although we do not know whether individual workers are covered, plants do report an estimate of the share of workers covered by the scheme in 2000, 2001 and 2005. Table 3 shows that the share of workers covered is rather higher than the (weighted) share of plants. Again, this will reflect the fact that large plants are more likely to have these schemes.

\section{Methodology \\ 4.1 Linear methods}

For simplicity, assume just two time periods. In the empirical work we relax this restriction. The basic estimating equation takes the form:

$$
\begin{aligned}
y_{j t}= & \beta_{P} P_{j t}+\beta_{S} S_{j t}+\beta_{D} D_{2 t}+\boldsymbol{\beta}_{\mathbf{x}} \mathbf{x}_{j t}+\theta_{j t}+\boldsymbol{\beta}_{\mathbf{w}} \mathbf{w}_{j t} \\
& +\psi_{j}+\epsilon_{j t}, \quad t=1,2
\end{aligned}
$$

where $y_{j t}$ is the plant-level average of $y_{i t}$, the earnings of worker $i$ at time $t$. The dummy variable $P_{j t}$ indicates whether the plant is operating profit-sharing in year $t$; the dummy variable $S_{j t}$ indicates whether the plant is operating a share ownership scheme in year $t$, and $D_{2 t}$ is a period-two dummy.

The set of characteristics which capture the productivity of the worker are a vector of observable characteristics $\mathbf{x}_{j t}$ and an unobservable component $\theta_{j t}$. Both of these components are averaged over all workers in the plant. Although each worker is assumed to have a time invariant unobserved productivity $\theta_{i}$, after averaging to the plant level it will vary over time because workers may join or leave the plant.

Similarly, the set of characteristics of a plant are divided into observable characteristics, captured by the vector $\mathbf{w}_{j t}$ 
and a time invariant unobserved component $\psi_{j}$. In theory, in a competitive labour market these terms should be unimportant: workers' compensation is determined solely by their marginal product, captured in this model by $\mathbf{x}_{i t}$ and $\theta_{i}$. But in practice it is well-known that earnings vary systematically across observably identical workers depending on the characteristics of their plant (such as industry, size and so on). Abowd et al. (1999), for example, show that variation in $\psi_{j}$ is an important component of total compensation.

As usual, ordinary-least-squares (OLS) estimates of $\beta_{P}$ and $\beta_{S}$ will be biased if any of the unobserved components of compensation are correlated with $P_{j t}$ or $S_{j t}$. The usual way to deal with this problem is to remove the fixed unobserved components by differencing. If we restrict the analysis to a balanced panel of plants, we can also deal with this problem using a simple panel difference-in-differences estimator. Define a treatment and control group:

$$
T_{j}= \begin{cases}1 & \text { if } P_{j 1}=0 \text { and } P_{j 2}=1 \\ 0 & \text { if } P_{j 1}=0 \text { and } P_{j 2}=0\end{cases}
$$

A similar definition can be applied for the introduction of share ownership, $S_{j t}$, but our data don't allow us to do this. See Footnote 12 below. Equation (1) can then be re-written as

$$
\begin{aligned}
y_{j t}= & \beta_{T} T_{j}+\beta_{D} D_{2 t}+\beta_{T D} T_{j} D_{2 t}+\beta_{\mathbf{x}} \mathbf{x}_{j t}+\theta_{j t} \\
& +\beta_{\mathbf{w}} \mathbf{w}_{j 1}+\epsilon_{j t} .
\end{aligned}
$$

In this model $\beta_{T}$ can be thought of as a selection effect. If plants in the treatment group had higher earnings before the introduction of a financial participation scheme this will be captured by $\beta_{T}$. Because the panel is balanced the treatment dummy $T_{j}$ captures any difference in average $\psi_{j}$ between the treatment and control groups, and so Eq. (2) is robust to any unobserved fixed differences between plants in the treatment and control groups. The difference-in-differences estimate of the treatment effect is captured by $\beta_{T D}$. This is the additional impact on compensation in the treatment group over and above the selection effect.

However, Eq. (2) still includes $\theta_{j t}$. In principle therefore a positive estimate of $\beta_{T D}$ could merely be the result of plants which introduce sharing arrangements selecting workers with higher $\theta_{i}$. Pannenberg and Spiess (2007), using household survey data, show that unobserved ability is an important determinant of the receipt of profit-sharing schemes. To deal with this, we also consider a variant of Eq. (2) which compares the compensation only of "stayers": workers who remain in the same plant in both periods. By definition, because we are looking at the same workers in both periods, $\theta_{j 1}=\theta_{j 2}$, and therefore any worker selection effect drops out of Eq. (2).
One further difference between Eqs. (1) and (2) is that in the latter we use plant characteristics from the "before" period only, $\mathbf{w}_{j 1} .{ }^{8}$ This is because, in theory, the introduction of financial participation could change other aspects of the plant captured by $\mathbf{w}_{j t}$ which might themselves affect worker compensation. ${ }^{9}$ In contrast, because we are interested in the impact of the introduction of financial participation on workers, we do allow for changes in the quality of the workforce captured by $\mathbf{x}_{j t}$ and $\theta j t$.

\subsection{Matching}

An alternative approach to control for differences in observed characteristics is to estimate the propensity to introduce financial participation schemes using a binary choice model (Probit) of the following form:

$$
\operatorname{Pr}\left(P_{j 2}=1\right)=\Phi\left(\gamma_{0}+\gamma_{\mathbf{x}} \mathbf{x}_{j 1}+\gamma_{\mathbf{w}} \mathbf{w}_{j 1}\right)
$$

We then use nearest-neighbour one-to-one matching without replacement to explicitly match plants from the treatment and control group whose propensity to introduce sharing is similar. The advantages and disadvantages of this approach compared to linear regression are summarised by Angrist and Pischke (2009, Sect. 3.3). The most significant effect of matching is that a plant in the treatment group whose propensity to start sharing arrangements is greater than any plant in the control group is not part of the comparison. ${ }^{10}$

\section{Results}

\subsection{Financial participation and average compensation}

Table 4 summarises all our basic estimates of Eq. (1). Row (1) shows the result of estimating Eq. (1) by OLS for the whole sample without controlling for observed or unobserved covariates. Our basic sample is 2000, 2001, 2005 and 2007 because this is when $P_{j t}$ and $S_{j t}$ are observed. However, information on individual workers from the Beschäftigtenstatistik is not available for 2007, so our first regression sample comprises 2000, 2001 and 2005 only. In the raw data, plants which have financial participation schemes have much higher total compensation, over 0.25 log-points more in the case of profit-sharing and over 0.18 log-points more in the case of share ownership. Of course,

\footnotetext{
${ }^{8}$ Which now also includes the measure of share ownership at $t=1, S_{j 1}$. In theory it is possible that $\beta_{T D}$ captures the effect of simultaneously introducing a profit-sharing scheme and a share ownership scheme. But in practice, less than ten plants are observed doing this.

${ }^{9}$ In practice this makes little difference because there is very little timeseries variation in $\mathbf{w}_{j t}$.

${ }^{10}$ Known as the off-support condition.
} 
Table 4 Profit-sharing, share ownership and total compensation: estimates of Eq. (1)

\begin{tabular}{lccc}
\hline & $\beta_{P}$ & $\beta_{S}$ & Sample size \\
\hline (1) Pooled OLS, no covariates & 0.256 & 0.185 & 28,774 \\
& $(0.006)$ & $(0.011)$ & \\
(2) Include $x_{j t}$ and $w_{j t}$ & 0.046 & 0.015 & 20,909 \\
& $(0.005)$ & $(0.008)$ & \\
(3) No singletons & 0.045 & 0.008 & 16,620 \\
& $(0.005)$ & $(0.009)$ & \\
(4) Fixed-effects & 0.007 & -0.002 & 16,620 \\
& $(0.003)$ & $(0.005)$ & \\
(5) Balanced panel (pooled OLS) & 0.040 & 0.014 & 7,638 \\
& $(0.008)$ & $(0.014)$ & \\
(6) Balanced panel first difference & 0.010 & -0.002 & 7,638 \\
\end{tabular}

Note: Standard errors in parentheses are all robust to clustering at the plant level. this raw difference partly reflects large differences in the observable characteristics of plants which operate these schemes. As noted, such plants are larger, situated in Western Germany, and in industries with high labour productivity.

We then include a rich set of observed plant and worker covariates. Means of $\mathbf{x}_{j t}$ and $\mathbf{w}_{j t}$ for different plant types are summarised in Tables 8 and 9 (in the Appendix). The results are shown in Row (2) of Table 4. The inclusion of covariates greatly reduces the estimated effect of financial participation. Profit-sharing is now associated with earnings which are 0.046 log-points higher, and share ownership with earnings which are just 0.015 log-points higher. The smaller effect of share ownership is unsurprising, because the value of any shares owned by workers will not be directly reflected in their annual compensation as measured by the Beschäftigtenstatistik. ${ }^{11}$ Thus any effect on $y_{j t}$ is an additional impact above the additional income from any shares held.

We now investigate whether various sample restrictions affect our result. In row (3) we show what happens when "singleton" plants (plants which were observed only once) are removed from the analysis. This is important because any panel data analysis always removes these plants. This has very little effect on the estimated value of $\beta_{P}$, but reduces the estimate of $\beta_{S}$ still further so that it is neither economically or statistically significant.

In row (4) we re-estimate Eq. (1), now removing the unobserved plant-level fixed component of earnings. This reduces the effect of financial participation on earnings still further. However, for a number of reasons this is not our preferred specification. First, as is well known, the fixed effects

\footnotetext{
${ }^{11}$ In contrast, workers' annual compensation does include any bonuses received as a result of profit-sharing.
}

estimates will be biased towards zero if there is measurement error in the explanatory variables. Second, this model does not use a clearly specified treatment and control group, and assumes that the impact of adopting financial participation is equal and opposite to the impact of stopping financial participation. For these reasons, we prefer to define the treatment and control groups more carefully.

Before we do this, in row (5) we further restrict the sample to a balanced panel of plants which are observed in 2000, 2001 and 2005. This is a significant sample restriction which is required if we are to estimate Eq. (2) on a welldefined treatment and control group. In row (6) we report first-differenced estimates of Eq. (1) on the balanced panel. In both cases the use of a balanced panel does not substantially change the estimated coefficients, so the estimates from row (5) are similar to those from row (2), and the estimates from row (6) are similar to those from row (4).

We now define the treatment and control groups more precisely for the introduction of profit-sharing. The control sample consists of those plants with $P_{j t}=0$ in 2000, 2001, 2005 and 2007. The treatment sample consists of those plants observed in the same four years which have $P_{j t}=0$ in 2000 and 2001, but which have $P_{j t}=1$ in both 2005 and 2007. This treatment group are called "adopters". The groups are defined in this way in order to reduce the possibility of measurement error, since we do not observe $P_{j t}$ in every year. A plant with $P_{j t}=1$ in 2005 and 2007 is very unlikely to have $P_{j t}=0$ in 2006. The precise date on which the financial participation scheme is introduced is not observed. Our definition of the treatment group implies that the profit-sharing scheme was introduced at some point between July 1st 2001 and June 30th 2005. ${ }^{12}$

\footnotetext{
${ }^{12}$ The number of plants in our sample who satisfy our rigorous definition of the treatment group for share ownership (no share ownership in 2000
} 
M. Andrews et al.

Table 5 Profit-sharing and total compensation: difference-in-difference estimates from Eq. (2)

\begin{tabular}{lcccc}
\hline & $\beta_{D}$ & $\beta_{T}$ & $\beta_{T D}$ & Sample size \\
\hline (1) No covariates & 0.057 & 0.277 & 0.057 & 3,304 \\
& $(0.005)$ & $(0.035)$ & $(0.013)$ & \\
(2) Include $x_{j t}$ and $w_{j 1}$ & 0.052 & 0.014 & 0.041 & 3,180 \\
& $(0.009)$ & $(0.019)$ & $(0.015)$ & \\
(3) Stayers & 0.056 & 0.022 & 0.052 & 2,986 \\
& $(0.016)$ & $(0.019)$ & $(0.012)$ & \\
(4) Movers & 0.041 & 0.022 & 0.023 & 2,542 \\
& $(0.010)$ & $(0.022)$ & $(0.029)$ & \\
(5) All workers, matched pairs & 0.086 & 0.037 & 0.025 & 332 \\
& $(0.012)$ & $(0.048)$ & $(0.018)$ & \\
\hline
\end{tabular}

Note: Standard errors in parentheses are all robust to clustering at the plant level.
Although compensation is defined as the average for the whole calendar year, $P_{j t}$ relates to 30 th June in each year. It is therefore possible that some of the compensation paid in 2001 and 2005 could fall inside the treatment window. The cleanest definition of compensation in the "before" and "after" periods are therefore those covering 2000 and 2006. We report various difference-in-differences estimates in Table 5.

Row (1) shows the raw difference-in-differences results from Eq. (2) without covariates. The estimate of $\beta_{T}$ shows that plants in the treatment sample (adopters) pay much more (0.27 log-points) before the adoption of profit-sharing. The estimate of $\beta_{T D}$ shows that, in addition, workers in plants which adopt profit-sharing also experience a significant increase in compensation of $0.057 \log$-points.

Row (2) also includes plant- and worker-level covariates. This has the effect of wiping out the selection effect $\left(\hat{\beta}_{T}=0.014\right.$ with a standard error of 0.019$)$, which implies that the pre-treatment difference in compensation between adopters and the control group is due to differences in these observed covariates. The additional impact of introducing profit-sharing is only slightly reduced to 0.041 log-points and is still highly significant (standard error 0.015).

Although the difference-in-differences (DiD) estimates control for any unobserved plant component of compensation, it is still possible that the positive effects of profit-sharing on total compensation are the result of worker turnover. For example, a plant which introduces profit-sharing might hire more highly paid workers and separate from more low-paid workers. In Eq. (2) this is captured by $\theta_{j t}$, the average unobserved worker component of compensation. In row (3), we therefore re-calculate the plant-level mean earnings, $y_{j t}$, and restrict the sample of workers to those who remain in the plant between 2000 and

and 2001, share ownership in 2005 and 2007) is very small (less than 20 plants), and so we do not estimate Eq. (2) in the case of share ownership schemes.
2006. Because we are now comparing the same workers in both periods, $\theta_{j 1}=\theta_{j 2}$, and therefore any worker selection effect drops out of Eq. (2).

Row (3) shows that the estimate of $\beta_{T D}$ for stayers is actually larger than for all workers, increasing to $0.052 \log$ points. In row (4) we also report estimates for workers who do not remain in the same plant between 2000 and 2006 . The estimate of $\beta_{D}$ tells us that the average compensation of workers who joined plants in the control group in 2006 was 0.041 log-points more than the average compensation of workers who left plants in the control group in 2000. The estimate of $\beta_{T}$ tells us that the average compensation of workers who left plants in the treatment group in 2000 was not significantly different from the average compensation of workers who left plants in the control group in 2000. Finally, the estimate of $\beta_{T D}$ tells us that the average compensation of workers who joined adopters was not significantly greater than the average compensation of workers who joined non-adopters, after controlling for any pre-selection effect $\left(\hat{\beta}_{T D}=0.023\right.$ with a standard error of 0.029 ). In short, rows (3) and (4) clearly show that the observed overall effect of introducing profit-sharing is not due to worker selection effects.

In row (5), we follow the method described in Sect. 4.2 and explicitly match plants in the treatment and control groups. The effect of matching is to greatly reduce the sample size because for each plant in the treatment group we draw just one plant in the control group. In Figs. 2 and 3 (in the Appendix) we plot the propensity scores for plants in the treatment and control group before and after matching, to show that the process of matching ensures that the propensity for adopting profit-sharing (as a function of observable characteristics) is far more similar after matching. ${ }^{13}$ After matching, the estimated treatment effect

\footnotetext{
${ }^{13} \mathrm{~A}$ series of $t$-tests of the means of $\mathbf{x}_{j t}$ and $\mathbf{w}_{j t}$ shows that matching also removes any significant difference in means for all covariates. Before
} 
Table 6 Profit-sharing and total compensation: departures from the base model

\begin{tabular}{|c|c|c|c|c|}
\hline & $\beta_{D}$ & $\beta_{T}$ & $\beta_{T D}$ & Sample size \\
\hline (1) Base model & $\begin{array}{c}0.052 \\
(0.009)\end{array}$ & $\begin{array}{c}0.014 \\
(0.019)\end{array}$ & $\begin{array}{c}0.041 \\
(0.015)\end{array}$ & 3,180 \\
\hline \multicolumn{5}{|c|}{ (2) Varying post-treatment effect by year } \\
\hline 2005 & $\begin{array}{c}0.028 \\
(0.008)\end{array}$ & $\begin{array}{c}0.009 \\
(0.018)\end{array}$ & $\begin{array}{c}0.043 \\
(0.012)\end{array}$ & \multirow[t]{2}{*}{4,920} \\
\hline 2006 & $\begin{array}{c}0.036 \\
(0.009)\end{array}$ & & $\begin{array}{c}0.043 \\
(0.013)\end{array}$ & \\
\hline \multicolumn{5}{|c|}{ (3) Interacted with proportion of workers affected by profit-sharing } \\
\hline$<20 \%$ & $\begin{array}{c}0.052 \\
(0.009)\end{array}$ & $\begin{array}{c}0.007 \\
(0.026)\end{array}$ & $\begin{array}{c}0.018 \\
(0.018)\end{array}$ & \multirow[t]{3}{*}{3,180} \\
\hline $20-99 \%$ & & $\begin{array}{c}0.023 \\
(0.045)\end{array}$ & $\begin{array}{c}0.078 \\
(0.040)\end{array}$ & \\
\hline $100 \%$ & & $\begin{array}{c}0.021 \\
(0.028)\end{array}$ & $\begin{array}{c}0.055 \\
(0.028)\end{array}$ & \\
\hline \multicolumn{5}{|c|}{ (4) Interacted with bargaining arrangements } \\
\hline No collective bargaining & $\begin{array}{c}0.052 \\
(0.009)\end{array}$ & $\begin{array}{c}0.029 \\
(0.032)\end{array}$ & $\begin{array}{c}0.026 \\
(0.027)\end{array}$ & \multirow[t]{2}{*}{3,180} \\
\hline Collective bargaining & & $\begin{array}{c}0.006 \\
(0.022)\end{array}$ & $\begin{array}{c}0.049 \\
(0.018)\end{array}$ & \\
\hline \multicolumn{5}{|c|}{ (5) Interacted with works council } \\
\hline No works council & $\begin{array}{c}0.052 \\
(0.009)\end{array}$ & $\begin{array}{c}0.062 \\
(0.034)\end{array}$ & $\begin{array}{c}0.023 \\
(0.027)\end{array}$ & \multirow[t]{2}{*}{3,177} \\
\hline Works council & & $\begin{array}{l}-0.021 \\
(0.019)\end{array}$ & $\begin{array}{c}0.045 \\
(0.017)\end{array}$ & \\
\hline \multicolumn{5}{|c|}{ (6) Interacted with plant size } \\
\hline$<20$ employees & $\begin{array}{c}0.052 \\
(0.009)\end{array}$ & $\begin{array}{c}0.093 \\
(0.060)\end{array}$ & $\begin{array}{c}0.010 \\
(0.050)\end{array}$ & \multirow[t]{3}{*}{3,180} \\
\hline 20-199 employees & & $\begin{array}{c}0.012 \\
(0.023)\end{array}$ & $\begin{array}{c}0.055 \\
(0.023)\end{array}$ & \\
\hline$>200$ employees & & $\begin{array}{l}-0.025 \\
(0.029)\end{array}$ & $\begin{array}{c}0.031 \\
(0.015)\end{array}$ & \\
\hline
\end{tabular}

Note: Standard errors in parentheses are all robust to clustering at the plant level. is now smaller and insignificantly different from zero $\left(\hat{\beta}_{T D}=0.025\right.$ with a standard error of 0.018$)$.

\subsection{Variation across plant characteristics}

In Table 6 we consider various departures from the model reported in row (2) of Table 5, which we regard as our base model. First, we include information from both the relevant post-treatment waves rather than just $t=2006$. This allows the impact of the introduction of financial participation to vary across 2005-2006. Equation (2) is modified so that there is an estimate of $\beta_{D}$ and an estimate of $\beta_{T D}$ for each post-treatment wave. Row (2) of Table 6 shows that the addition to earnings after the introduction of profit-sharing is very stable.

Although the data do not record which individuals are covered by the profit-sharing agreement, they do record

matching 31 out of 61 covariates had significantly different means between the treatment and control groups; after matching none of the means were significantly different at $10 \%$ significance levels. what proportion of workers in a plant are covered. It seems likely that the strength of any earnings effect will vary with the proportion. In row (3) we modify Eq. (2) by interacting $T_{j}$ and $T_{j} D_{2 t}$ with the proportion of workers covered by profit-sharing. The results show that the DiD earnings effect is insignificantly different from zero in plants with a low proportion of workers covered $(0.018$ log-points with a standard error of 0.018), while the effect is larger and significant for plants with a higher proportion of workers covered $(0.055$ with a standard error of 0.028$)$.

We would expect that the industrial relations environment in the plant would have an effect on the introduction of profit-sharing. As noted by Welz and Macias (2007), when unions agree to the introduction of financial participation schemes, it typically depends on an implicit agreement that basic wages will be protected. In rows (4) and (5) we investigate this by interacting $T_{j}$ and $T_{j} D_{2 t}$ with dummy variables indicating whether the plant bargains with unions (either at the plant or sectoral level) or whether the plant operates a works council. In both cases our prior hypothesis is confirmed: the DiD estimate is larger and significant in 
Table 7 Profit-sharing and total compensation: variation across worker type

\begin{tabular}{|c|c|c|c|c|}
\hline & $\beta_{D}$ & $\beta_{T}$ & $\beta_{T D}$ & Sample size \\
\hline (1) Base model & $\begin{array}{c}0.052 \\
(0.009)\end{array}$ & $\begin{array}{c}0.014 \\
(0.019)\end{array}$ & $\begin{array}{c}0.041 \\
(0.015)\end{array}$ & 3,180 \\
\hline \multicolumn{5}{|l|}{ (2) Gender } \\
\hline Male & $\begin{array}{c}0.033 \\
(0.009)\end{array}$ & $\begin{array}{c}0.013 \\
(0.020)\end{array}$ & $\begin{array}{c}0.050 \\
(0.015)\end{array}$ & 2,741 \\
\hline Female & $\begin{array}{c}0.047 \\
(0.012)\end{array}$ & $\begin{array}{c}0.033 \\
(0.026)\end{array}$ & $\begin{array}{c}0.032 \\
(0.025)\end{array}$ & 2,394 \\
\hline \multicolumn{5}{|l|}{ (3) Age } \\
\hline$\leq 40$ years & $\begin{array}{c}0.030 \\
(0.008)\end{array}$ & $\begin{array}{c}0.020 \\
(0.020)\end{array}$ & $\begin{array}{c}0.024 \\
(0.017)\end{array}$ & 2,596 \\
\hline$>40$ years & $\begin{array}{c}0.047 \\
(0.011)\end{array}$ & $\begin{array}{c}0.025 \\
(0.021)\end{array}$ & $\begin{array}{c}0.040 \\
(0.015)\end{array}$ & 2,716 \\
\hline \multicolumn{5}{|l|}{ (4) Tenure } \\
\hline$\leq 10$ years & $\begin{array}{c}0.034 \\
(0.007)\end{array}$ & $\begin{array}{c}0.013 \\
(0.018)\end{array}$ & $\begin{array}{c}0.034 \\
(0.020)\end{array}$ & 2,826 \\
\hline$>10$ years & $\begin{array}{c}0.052 \\
(0.013)\end{array}$ & $\begin{array}{c}0.011 \\
(0.028)\end{array}$ & $\begin{array}{c}0.054 \\
(0.022)\end{array}$ & 949 \\
\hline \multicolumn{5}{|l|}{ (5) Occupation } \\
\hline Low-skilled blue-collar & $\begin{array}{c}0.057 \\
(0.012)\end{array}$ & $\begin{array}{c}0.023 \\
(0.026)\end{array}$ & $\begin{array}{c}0.027 \\
(0.022)\end{array}$ & 1,251 \\
\hline Medium-skilled blue-collar & $\begin{array}{c}0.039 \\
(0.010)\end{array}$ & $\begin{array}{c}-0.026 \\
(0.024)\end{array}$ & $\begin{array}{c}0.030 \\
(0.016)\end{array}$ & 1,753 \\
\hline High-skilled blue collar & $\begin{array}{c}0.051 \\
(0.014)\end{array}$ & $\begin{array}{c}0.010 \\
(0.025)\end{array}$ & $\begin{array}{c}0.055 \\
(0.020)\end{array}$ & 1,054 \\
\hline Low-skilled white-collar ${ }^{\mathrm{a}}$ & $\begin{array}{l}0.024 \\
0.012\end{array}$ & $\begin{array}{l}0.018 \\
0.029\end{array}$ & $\begin{array}{l}0.052 \\
0.028\end{array}$ & 1,471 \\
\hline Medium-skilled white-collar ${ }^{b}$ & $\begin{array}{c}0.063 \\
(0.012)\end{array}$ & $\begin{array}{c}0.001 \\
(0.023)\end{array}$ & $\begin{array}{c}0.032 \\
(0.018)\end{array}$ & 1,943 \\
\hline Managers $^{c}$ & $\begin{array}{c}0.098 \\
(0.017)\end{array}$ & $\begin{array}{c}0.001 \\
(0.023)\end{array}$ & $\begin{array}{c}0.025 \\
(0.029)\end{array}$ & 864 \\
\hline
\end{tabular}

Note: Standard errors in parentheses are all robust to clustering at the plant level.

a "Basic service occupations" and "Basic business occupations" grouped together (see Table 9 in the Appendix).

b "Qualified service occupations", "Semi-professional" and "Qualified business occupations" grouped together.

c "Professional" and "Manager" grouped together. the presence of union bargaining or works councils. Of course, this might be picking up a plant size effect, since bargaining and works councils are strongly associated with larger plants. Row (6) confirms that the earnings effect is insignificant in small plants, but larger and significant in plants employing more than 20 workers.

\subsection{Variation across worker characteristics}

Most of our results reported in the previous sub-section suggest that the introduction of profit-sharing is associated with modest increases in plant-level earnings of between 2 and $5 \%$. However, in a smaller sample of matched pairs the increase is insignificantly different from zero. At the very least, we can say that workers are not worse off in terms of average earnings from the introduction of profit-sharing.

However, the introduction of profit-sharing within a plant may well have different effects on different groups of workers. As we have seen in Table 6, not all workers are covered by the profit-sharing scheme. In addition, different groups of workers may have different profit-sharing arrangements. Managers and more senior workers, for example, might have their total compensation more closely linked to the profits of the plant. This implies that the introduction of profit-sharing might have effects on the distribution of earnings within plants.

To examine the variation in $\beta_{T D}$ across worker characteristics, we estimate Eq. 2 separately by sex, age, tenure and occupation. To do this we compute $y_{j t}$ and $x_{j t}$ for 
each subgroup. ${ }^{14}$ Column (3) of Table 7 reports estimates of $\beta_{T D}$ for each subgroup. The impact of profit-sharing is slightly larger for men, for older workers and for workers who have been in their plant for more than 10 years. This might reflect the fact that within the plant, the incidence of profit-sharing schemes is greater for these groups.

The relationship between occupation and the earnings effect of profit-sharing is less obvious. We anticipated that more highly skilled white collar workers (in particular managers) might benefit more from profit-sharing schemes. In fact, we find that while the effect is increasing in skill for blue-collar workers, it is decreasing in skill for white-collar workers, to the extent that managers compensation is not significantly affected by the presence of plant-level profitsharing. Thus it appears that, in this data, the introduction of profit-sharing cannot be blamed for increasing dispersion in earnings between managers and workers.

Furthermore, note that all of these estimates are very stable across groups. All subgroup estimates are within approximately one standard error of the pooled baseline estimate of $\beta_{T D}=0.041(0.015)$, and we cannot reject the hypothesis that $\beta_{T D}$ is equal across any of the different worker types. In other words, we find no evidence that the introduction of profit-sharing schemes increases wages more for some groups of workers than others. ${ }^{15}$

\section{Conclusion}

In this paper we provide evidence on the relationship between the use of financial participation schemes and worker compensation using a large linked panel of German plants. The data allow us to measure total worker compensation, including any bonus payments which arise as a result of profitsharing schemes. We are also able to control for a wide range of worker and plant characteristics which might affect the use of profit-sharing schemes and total compensation. The use of linked worker-plant panel data allows us to control for unobserved plant and worker effects on compensation. We are also able to examine how the compensation effect varies over different types of plant and different types of worker.

Our findings are as follows:

1. The incidence of financial participation schemes in Germany has not increased significantly over the period 2001-2007, and in fact the use of employee share ownership arrangements appears to have declined slightly.

\footnotetext{
${ }^{14}$ This means that if any plants employ no workers in that subgroup, they will not appear in that regression. For example, a plant which employs no men will not appear in the male regression.

${ }^{15}$ It is however possible that this result occurs because we cannot identify which individual workers are covered by the profit-sharing scheme.
}

2. The use of financial participation is much higher in large plants and in sectors with low labour intensity.

3 . Workers in plants which operate financial participation schemes earn significantly more: $25 \%$ in the case of profit-sharing and $18 \%$ in the case of share ownership. The larger effect of profit-sharing on earnings is entirely unsurprising, since our measure of earnings includes bonuses.

4. Econometric models which deal with selection by plants and workers into profit-sharing schemes suggest that the earnings effect is much smaller: between 0.041 log-points (from a difference-in-difference regression) and 0.025 log-points (from a comparison of matched pairs). The estimate from a comparison of matched pairs is not significantly different from zero at conventional significance levels.

5. The earnings effect of profit-sharing is larger for plants with a higher proportion of workers covered, for plants with collective bargaining arrangements and for plants with works councils.

6. The effect of profit-sharing on earnings is very consistent across different types of workers. We find no evidence that certain groups of workers benefit significantly more from the introduction of profit-sharing schemes.

In conclusion, workers in German plants have little to fear from the introduction of profit-sharing schemes. In almost all our specifications we find that profit-sharing is associated with modest increases in workers' total compensation, and we find no evidence that any particular groups of workers are significantly penalised. If the differences between plants which introduce profit-sharing and those which do not can be regarded as fixed over time, then our estimates represent causal impacts of profit-sharing on worker compensation. However, if the introduction of profit-sharing is associated with simultaneous increases in plant performance from some unobserved factors, then our estimates should not be interpreted as causal impacts.

\section{Executive summary}

The financial participation of employees in their firm, in the form of profit-sharing or share ownership, continues to increase across almost all European countries, albeit from a low level in many of them. These schemes have been encouraged by most European governments via the use of tax incentives and legislation.

Economists have argued that profit-sharing could lower the marginal cost of hiring workers and therefore permanently increase the level of employment. However, a key finding of the empirical literature on profit-sharing is that the introduction of such schemes is not generally associated 
with reductions in the basic wage. A second finding of the empirical literature is that the introduction of profit schemes is associated with higher productivity. These two findings might be linked: if the introduction of profit-sharing leads to higher total compensation for workers, this might explain higher productivity, either because of worker selection or efficiency wage mechanisms. In contrast, some workers' representatives have argued against the introduction of profitsharing because they fear that profit-sharing would be a way for firms to reduce the marginal cost of hiring workers, while at the same time transferring some of the risk of variable profits from firms to workers.

In this paper we provide detailed evidence on the relationship between the use of financial participation schemes and total worker compensation using the IAB Establishment Panel, linked to Social Security data on the workers in those plants. We are able to control for a wide range of worker and plant characteristics which might affect the use of financial participation schemes as well as total compensation. The use of linked worker-plant panel data also allows us to control for unobserved plant and worker effects on compensation by comparing plants which introduce profit-sharing with similar plants which do not. Thus, we provide new evidence on how much workers gain from financial participation in their firms.

We can also examine whether the introduction of financial participation has an effect on the selection of workers in and out of the plant. In theory, workers' preferences for increased risk (or plants' preferences for workers with certain characteristics) could lead to changes in the composition of the workforce. By comparing workers who remain in the plant with those who join or leave we can effectively control for this when calculating the effect on workers' compensation.

The use of linked worker-plant data also allows us to examine whether financial participation has effects on the distribution of compensation across different types of worker. Recent evidence from the United States suggests that the increasing use of performance pay has resulted in greater wage inequality amongst workers who receive performance pay. In this paper we examine whether the introduction of profit-related pay has differential affects on workers' compensation according to their sex, age, tenure and occupation.

We find that

1. The incidence of financial participation schemes in Germany has not increased significantly over the period 2001-2007, and in fact the use of employee share ownership arrangements appears to have declined slightly.

2. The use of financial participation is much higher in large plants and in sectors with low labour intensity.

3. Workers in plants which operate financial participation schemes earn significantly more: $25 \%$ in the case of profit-sharing and $18 \%$ in the case of share ownership. The larger effect of profit-sharing on earnings is entirely unsurprising, since our measure of earnings includes bonuses.

4. Econometric models which deal with selection by plants and workers into profit-sharing schemes suggest that the earnings effect is much smaller: between about $4 \%$ (from a difference-in-difference regression) and 2.5\% (from a comparison of matched pairs of establishments). The estimate from a comparison of matched pairs is not significantly different from zero at conventional significance levels.

5. The earnings effect of profit-sharing is larger for plants with a higher proportion of workers covered, for plants with collective bargaining arrangements and for plants with works councils.

6. The effect of profit-sharing on earnings is very consistent across different types of workers. We find no evidence that certain groups of workers benefit significantly more from the introduction of profit-sharing schemes.

We conclude that workers in German plants have little to fear from the introduction of profit-sharing schemes. In almost all our specifications we find that profit-sharing is associated with modest increases in workers' total compensation, and we find no evidence that any particular groups of workers are significantly penalised.

\section{Kurzfassung}

Die finanzielle Mitarbeiterbeteiligung in Formen der Gewinn- oder Kapitalbeteiligung nimmt in fast allen europäischen Ländern weiterhin $\mathrm{zu}$, trotz des niedrigen Niveaus in vielen von ihnen. Die Einführung von Systemen der Mitarbeiterbeteiligung wurde auch von den meisten europäischen Regierungen durch die Gewährung von steuerlichen Vorteilen und gesetzlichen Vorgaben gefördert.

Aus ökonomischer Sicht kann die Gewinnbeteiligung die Grenzkosten der Einstellung von Arbeitskräften senken und damit das Niveau der Beschäftigung dauerhaft erhöhen. Ein zentrales Ergebnis der empirischen Literatur zur Gewinnbeteiligung besteht jedoch darin, dass die Einführung dieser Systeme im Allgemeinen nicht mit einer Senkung des Grundlohns verbunden ist. Ein anderer empirischer Befund ist, dass Gewinnbeteiligung mit einer höheren Produktivität korreliert. Diese beiden Ergebnisse können wie folgt miteinander verbunden werden: Wenn die Einführung von Gewinnbeteiligung die Gesamtentlohnung der Beschäftigten erhöht, kann dies die höhere Produktivität erklären - entweder aufgrund der Selektion der Beschäftigten oder aufgrund der Zahlung von Effizienzlöhnen. Im Gegensatz dazu haben die Arbeitnehmervertreter sich oft 
gegen die Einführung von Gewinnbeteiligungssystemen ausgesprochen, denn sie befürchten, dass auf diesem Weg die Unternehmen zwar die Einstellungskosten senken, gleichzeitig aber auch einen Teil des Risikos variierender Gewinne auf die Beschäftigten verlagern.

In unserem Beitrag präsentieren wir detaillierte Ergebnisse für die Beziehung zwischen der Nutzung von Systemen der finanziellen Mitarbeiterbeteiligung und der Gesamtentlohnung der Beschäftigten auf der Basis der Daten des IAB-Betriebspanels, die mit den Daten der Beschäftigtenstatistik gematcht wurden. Damit sind wir in der Lage, für eine große Anzahl von Merkmalen der Beschäftigten und der Betriebe zu kontrollieren, welche Merkmale die Nutzung der finanziellen Mitarbeiterbeteiligung und die Gesamtentlohnung bestimmen. Außerdem erlaubt die Verwendung der gematchten Beschäftigtenbetriebsdaten eine Kontrolle für unbeobachtete Betriebs- und Beschäftigteneffekte auf die Entlohnung. Dazu werden Betriebe, die Systeme der Gewinnbeteiligung eingeführt haben, mit solchen verglichen, die diesen Schritt nicht gegangen sind. Somit ermitteln wir empirisch, in welchem Umfang die Beschäftigten durch Gewinnbeteiligungssysteme besser gestellt werden.

Wir können auch untersuchen, ob die Einführung von Systemen der finanziellen Mitarbeiterbeteiligung selektiv auf die Einstellung und Entlassung von Beschäftigten wirkt. Theoretisch können Präferenzen der Beschäftigten für ein höheres Risiko (oder die Präferenzen der Betriebe für Beschäftigte mit bestimmten Merkmalen) zu Veränderungen in der Mitarbeiterstruktur von Betrieben führen. Indem wir Beschäftigte, die im Betrieb verbleiben, mit solchen, die den Betrieb wechseln, vergleichen, können wir für diesen Effekt auf die Entlohnung der Beschäftigten kontrollieren.

Die Nutzung von gematchten Beschäftigtenbetriebsdaten erlaubt es uns außerdem, zu untersuchen, ob sich die finanzielle Beteiligung der Mitarbeiter auf die Entlohnung unterschiedlicher Typen von Beschäftigten auswirkt. Neuere Studien aus den USA legen nahe, dass die zunehmende Verwendung von leistungsabhängigen Entlohnungselementen zu einer größeren Lohnungleichheit unter den Beschäftigten, die leistungsabhängig entlohnt werden, geführt hat. In diesem Artikel untersuchen wir, ob die Einführung von Gewinnbeteiligungssystemen unterschiedliche Effekte auf die Entlohnung von Beschäftigten hat, die sich hinsichtlich ihres Geschlechts, ihres Alters, ihres Berufs und der Dauer ihrer Betriebszugehörigkeit unterscheiden.

Unsere Ergebnisse zeigen, dass

1. sich die Verbreitung von Systemen der finanziellen Mitarbeiterbeteiligung im Zeitraum 2001-2007 nicht signifikant erhöht hat. Dabei ging die Nutzung der Kapitalbeteiligungssysteme sogar leicht zurück.

2. Systeme der finanziellen Mitarbeiterbeteiligung häufiger in großen Betrieben und in Wirtschaftssektoren mit niedriger Arbeitsintensität zu finden sind.

3. Beschäftigte, die in Betrieben mit Systemen der finanziellen Mitarbeiterbeteiligung arbeiten, signifikant mehr verdienen: $25 \%$ bei Gewinnbeteiligung und $18 \%$ bei Kapitalbeteiligung. Der größere Effekt bei Gewinnbeteiligung ist nicht überraschend, denn die in der Beschäftigtenstatistik erfassten Einkommen enthalten Leistungsprämien und Boni.

4. die eine Selektion der Beschäftigten und Betriebe in Systeme der Gewinnbeteiligung berücksichtigenden ökonometrischen Modelle niedrigere Lohneffekte aufweisen: Sie liegen zwischen 4 (bei einer Differenz-in-Differenzen-Regression) und 2,5\% (bei einem Vergleich von paarweise gematchten Betrieben), wobei die zuletzt genannten Ergebnisse nicht mehr signifikant sind.

5. der Einkommenseffekt der Gewinnbeteiligung größer ist für Betriebe, die mehr Beschäftigte in Systeme der Gewinnbeteiligung einbeziehen.

6. der Einkommenseffekt der Gewinnbeteiligung für verschiedene Typen von Beschäftigten sehr konsistent ist. Unsere Ergebnisse zeigen, dass sich bestimmte Gruppen von Beschäftigten signifikant mehr als andere durch die Einführung von Gewinnbeteiligungssystemen verbessern.

Zusammenfassend brauchen sich die Beschäftigten in deutschen Betrieben wenig vor der Einführung von Gewinnbeteiligungssystemen zu fürchten. In fast allen Modellspezifikationen zeigt sich, dass Gewinnbeteiligung mit leichten Einkommensverbesserungen für die Beschäftigten verbunden ist. Dabei finden wir keine empirische Evidenz dafür, dass einzelne Gruppen von Beschäftigten Nachteile erleiden. 


\section{Appendix}

\section{A.1 Figures}

Fig. 2 Propensity score of treated and untreated plants, unmatched

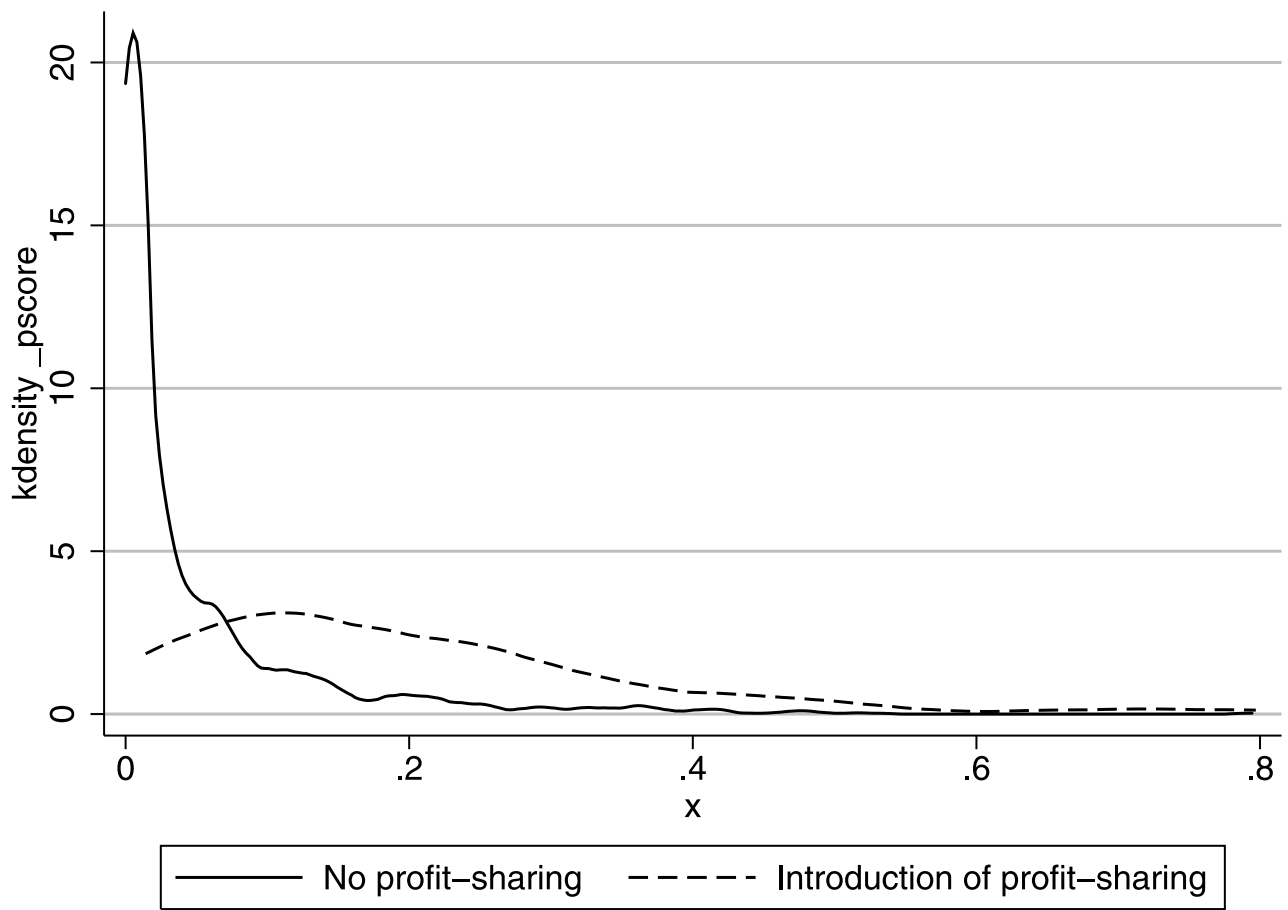

Fig. 3 Propensity score of treated and untreated plants, matched

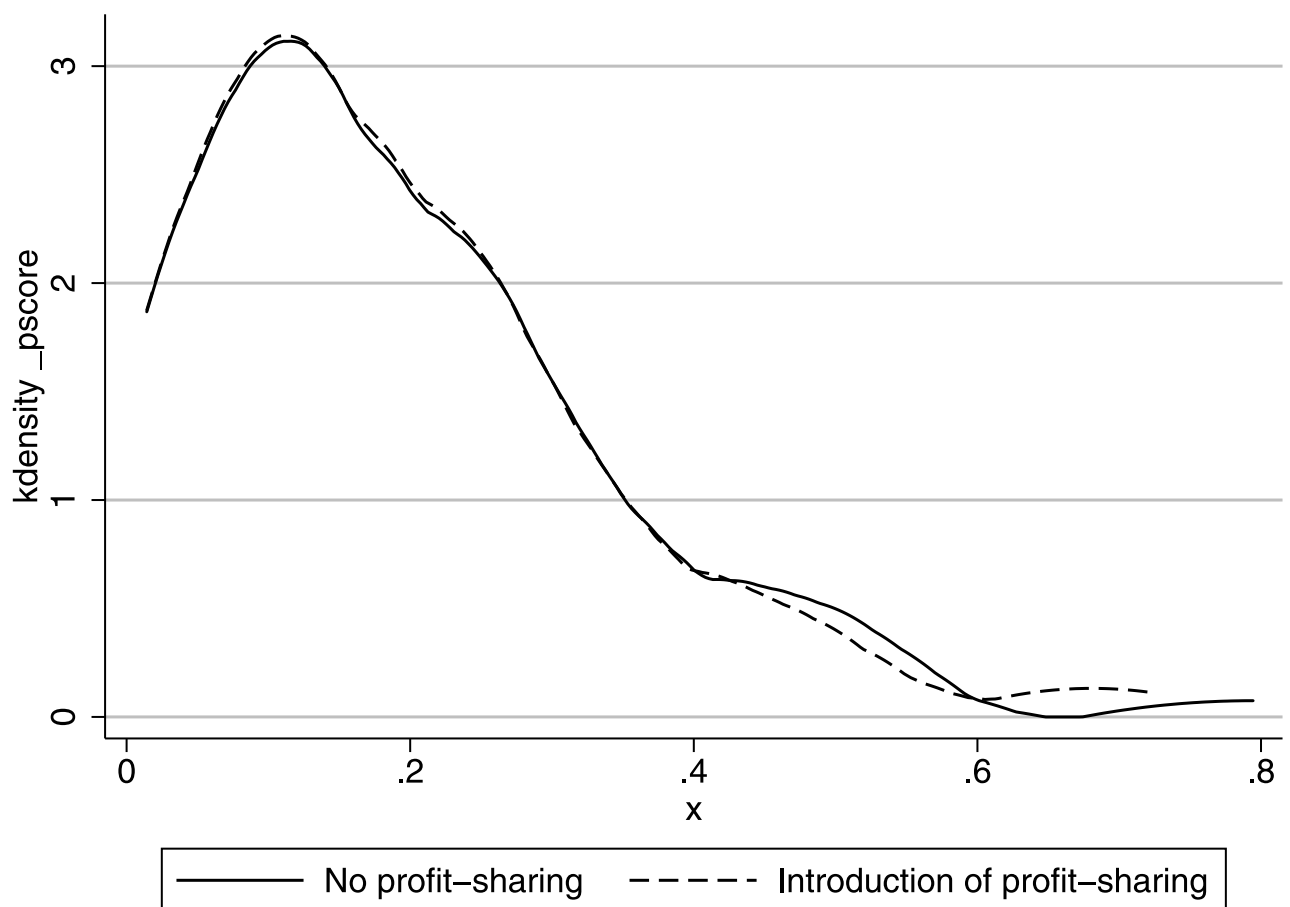




\section{A.2 Tables}

Table 8 Means of plant covariates by plant type

\begin{tabular}{|c|c|c|c|c|}
\hline & $P_{j t}=0$ & $P_{j t}=1$ & $S_{j t}=0$ & $S_{j t}=1$ \\
\hline Works council & 0.279 & 0.568 & 0.312 & 0.668 \\
\hline Bargaining at sectoral level & 0.441 & 0.536 & 0.451 & 0.581 \\
\hline Bargaining at firm level & 0.070 & 0.089 & 0.072 & 0.109 \\
\hline Plant has new technology & 0.672 & 0.775 & 0.684 & 0.801 \\
\hline Workers receive overtime & 0.403 & 0.610 & 0.430 & 0.615 \\
\hline Plant born 1990-1994 & 0.337 & 0.264 & 0.328 & 0.263 \\
\hline Plant born after 1995 & 0.144 & 0.132 & 0.141 & 0.164 \\
\hline Plant not part of a larger firm & 0.790 & 0.529 & 0.762 & 0.404 \\
\hline Plant located in Eastern Germany & 0.421 & 0.267 & 0.401 & 0.284 \\
\hline 5-9 employees & 0.175 & 0.069 & 0.161 & 0.077 \\
\hline 10-19 employees & 0.160 & 0.094 & 0.152 & 0.076 \\
\hline 20-49 employees & 0.197 & 0.186 & 0.197 & 0.159 \\
\hline 50-99 employees & 0.109 & 0.140 & 0.114 & 0.115 \\
\hline 100-199 employees & 0.083 & 0.133 & 0.090 & 0.117 \\
\hline 200-499 employees & 0.078 & 0.156 & 0.089 & 0.136 \\
\hline 500-999 employees & 0.029 & 0.085 & 0.036 & 0.098 \\
\hline$\geq 1,000$ employees & 0.020 & 0.103 & 0.027 & 0.189 \\
\hline Mining, energy & 0.014 & 0.022 & 0.015 & 0.029 \\
\hline Food manufacturing & 0.040 & 0.027 & 0.038 & 0.027 \\
\hline Consumer goods manufacturing & 0.054 & 0.039 & 0.052 & 0.033 \\
\hline Producer goods manufacturing & 0.116 & 0.128 & 0.118 & 0.128 \\
\hline Investment goods manufacturing & 0.158 & 0.238 & 0.169 & 0.223 \\
\hline Construction & 0.134 & 0.068 & 0.125 & 0.073 \\
\hline Wholesale and retail trade & 0.168 & 0.175 & 0.170 & 0.141 \\
\hline Transport and communications & 0.048 & 0.043 & 0.048 & 0.040 \\
\hline Financial services & 0.010 & 0.039 & 0.011 & 0.095 \\
\hline Hotels and restaurants & 0.031 & 0.018 & 0.030 & 0.010 \\
\hline Education & 0.011 & 0.010 & 0.011 & 0.010 \\
\hline Health services & 0.055 & 0.023 & 0.051 & 0.013 \\
\hline Business services & 0.106 & 0.133 & 0.109 & 0.148 \\
\hline Other services & 0.034 & 0.025 & 0.034 & 0.009 \\
\hline
\end{tabular}


Table 9 Means of worker covariates by plant type

\begin{tabular}{|c|c|c|c|c|}
\hline & $P_{j t}=0$ & $P_{j t}=1$ & $S_{j t}=0$ & $S_{j t}=1$ \\
\hline Average age $21-30$ & 0.172 & 0.159 & 0.171 & 0.151 \\
\hline Average age $31-40$ & 0.316 & 0.333 & 0.318 & 0.347 \\
\hline Average age $41-50$ & 0.306 & 0.306 & 0.306 & 0.308 \\
\hline Average age 51-55 & 0.109 & 0.112 & 0.109 & 0.116 \\
\hline Average age 56-65 & 0.093 & 0.087 & 0.093 & 0.076 \\
\hline Average tenure $1-2$ years & 0.120 & 0.113 & 0.119 & 0.116 \\
\hline Average tenure $2-5$ years & 0.246 & 0.236 & 0.246 & 0.227 \\
\hline Average tenure $6-10$ years & 0.351 & 0.300 & 0.343 & 0.315 \\
\hline Average tenure $11-15$ years & 0.122 & 0.141 & 0.125 & 0.127 \\
\hline Average tenure $16-20$ years & 0.042 & 0.056 & 0.044 & 0.053 \\
\hline Average tenure $21-25$ years & 0.034 & 0.046 & 0.035 & 0.051 \\
\hline Average tenure $>25$ years & 0.027 & 0.042 & 0.029 & 0.043 \\
\hline \multicolumn{5}{|l|}{ Proportion of workers: } \\
\hline Multiple jobs & 0.032 & 0.033 & 0.033 & 0.028 \\
\hline German workers & 0.957 & 0.947 & 0.955 & 0.956 \\
\hline females & 0.352 & 0.298 & 0.346 & 0.272 \\
\hline Apprenticeship, no Abitur & 0.689 & 0.636 & 0.683 & 0.623 \\
\hline Abitur, no Apprenticeship & 0.004 & 0.008 & 0.005 & 0.010 \\
\hline Apprenticeship and Abitur & 0.030 & 0.050 & 0.032 & 0.061 \\
\hline Technical College Degree & 0.028 & 0.049 & 0.031 & 0.058 \\
\hline University Education & 0.033 & 0.068 & 0.036 & 0.095 \\
\hline Unknown education & 0.133 & 0.102 & 0.130 & 0.082 \\
\hline Qualified manual occupation & 0.256 & 0.182 & 0.246 & 0.181 \\
\hline Engineers and technicians & 0.083 & 0.128 & 0.089 & 0.144 \\
\hline Basic service occupation & 0.115 & 0.089 & 0.112 & 0.070 \\
\hline Qualified service occupation & 0.054 & 0.030 & 0.052 & 0.018 \\
\hline Semi-professional & 0.018 & 0.014 & 0.017 & 0.013 \\
\hline Professional & 0.012 & 0.011 & 0.012 & 0.010 \\
\hline Basic business occupation & 0.071 & 0.072 & 0.071 & 0.071 \\
\hline Qualified business occupation & 0.173 & 0.247 & 0.181 & 0.268 \\
\hline Manager & 0.037 & 0.046 & 0.038 & 0.050 \\
\hline
\end{tabular}

\section{References}

Abowd, J., Kramarz, F., Margolis, D.: High wage workers and high wage firms. Econometrica 67(2), 251-333 (1999)

Angrist, J., Pischke, J.-S.: Mostly Harmless Econometrics. Princeton University Press, Princeton and Oxford (2009)

Bellmann, L., Möller, I.: Profit-sharing and employment stability. Schmalenbach Bus. Rev. 62(1), 73-92 (2010)

Bender, S., Haas, A., Klose, C.: The IAB employment subsample 1975-1999. Schmollers Jahrb. 120(4), 649-662 (2000)

Bhargava, S., Jenkinson, T.: Explicit versus implicit profit sharing and the determination of wages: Microeconomic evidence from the UK. Labour 9(1), 73-95 (1995)

Blasi, J., Freeman, R., Mackin, C., Kruse, D.: Creating a bigger pie? The effects of employee ownership, profit sharing, and stock options on workplace performance. NBER working paper 14230 (2008)

Buchele, R., Kruse, D., Rodgers, L., Scharf, A.: Show me the money: Does shared capitalism share the wealth? NBER working paper 14830 (2009)

Cable, J., Wilson, N.: Profit-sharing and productivity: An analysis of UK engineering firms. Econ. J. 90(396), 366-375 (1989)
Carstensen, V., Gerlach, K., Hübler, O.: Profit sharing in German firms. In: Buttler, F., Franz, W., Schettkat, R., Soskice, D. (eds.): Institutional Frameworks and Labor Market Performance, pp. 168-207. Routledge, London and New York (1995)

Commission of the European Communities: Pepper II: Promotion of Participation by Employed Persons in Profits and Enterprise Results. Brussels (1996)

Cuñat, V., Guadalupe, M.: Globalization and the provision of incentives inside the firm: The effect of foreign competition. J. Labor Econ. 27(2), 179-212 (2009)

Doucouliagos, C.: Worker participation and productivity in labormanaged and participatory capitalist firms: A meta-analysis. Ind. Labor Relat. Rev. 49(1), 58-77 (1995)

Estrin, S., Wilson, N.: The microeconomic effects of profit-sharing: the British experience. Centre for Labour Economics discussion paper 247 (1986)

Fischer, G., Janik, F., Müller, D., Schmucker, A.: The IAB Establishment Panel - things users should know. Schmollers Jahrb. 129(1), 133-148 (2009)

FitzRoy, F., Kraft, K.: Cooperation, productivity and profit sharing. Q. J. Econ. 102(1), 23-35 (1987) 
FitzRoy, F., Kraft, K.: On the choice of incentives in the firm. J. Econ. Behav. Organ. 26(1), 145-160 (1995)

Freeman, R.: When workers share in profits: Effort and responses to shirking. CEP discussion paper 882 (2008)

Hart, R., Hübler, O.: Are profit shares and wages substitute or complementary forms of compensation? Kyklos 44(2), 221-231 (1991)

Jones, D. C., Kato, T.: The productivity effects of employee stockownership plans and bonuses: Evidence from Japanese panel data. Am. Econ. Rev. 85(3), 391-414 (1995)

Knez, M., Simester, D.: Firm-wide incentives and mutual monitoring at Continental Airlines. J. Labor Econ. 19(4), 743-772 (2001)

Kraft, K., Ugarković, M.: Profit sharing and the financial performance of firms: Evidence from Germany. Econ. Lett. 92(3), 333-338 (2006)

Kruse, D. L.: Profit sharing and productivity: Microeconomic evidence from the United States. Econ. J. 102(410), 24-36 (1992)

Kruse, D. L.: Does profit sharing affect productivity? NBER working paper 4542 (1993)

Kruse, D. L., Freeman, R., Blasi, J.: Do workers gain by sharing? Employee outcomes under employee ownership, profit sharing, and broad-based stock options. NBER working paper 14233 (2008)

Lemieux, T., MacLeod, W., Parent, D.: Performance pay and wage inequality. Q. J. Econ. 74(1), 1-49 (2009)

Pannenberg, M., Spiess, M.: GEE estimation of a two-equation panel data model: An analysis of wage dynamics and the incidence of profit-sharing in Germany. DIW discussion paper 663 (2007)

Prendergast, C.: The provision of incentives in firms. J. Econ. Lit. 37(1), 7-63 (1999)

Von Thünen, J.: Der isolierte Staat in Beziehung auf Landwirtschaft und Nationalökonomie, zweiter Teil: Der naturgemäße Arbeitslohn und dessen Verhältnis zu Zinsfuß und zur Laudrente. Leopold, Rostock (1850)

Wadhwani, S., Wall, M.: The effects of profit-sharing on employment, wages, stock returns and productivity: Evidence from UK microdata. Econ. J. 100(399), 1-17 (1990)

Weiss, A.: Incentives and worker behaviour. NBER working paper 2194 (1987)

Weitzman, M.: The Share Economy. Harvard University Press, Cambridge, MA (1984)

Weitzman, M.: Steady-state unemployment under profit-sharing. Econ. J. 97(385), 86-105 (1987)

Welz, C., Macias, E.: Financial participation of employees in the European Union: Much ado about nothing? European Foundation for the Improvement of Living and Working Conditions, Dublin (2007)

Wilson, N., Cable, J., Peel, M.: Quit rates and the impact of participation, profit-sharing and unionization: Empirical evidence from UK engineering firms. Brit. J. Ind. Relat. 28(2), 198-211 (1990)

Wilson, N., Peel, M.: The impact on absenteeism and quits of profitsharing and other forms of employee participation. Ind. Labor Relat. Rev. 44(3), 454-468 (1991)
Martyn Andrews is a Professor of Applied Econometrics at the University of Manchester. He is a member of the Royal Economic Society and the European Association of Labour Economists, and he is an Editor of the Manchester School.

His research interests are in mainstream applied labour economics, using large-scale micro- and panel-datasets. These include: training and matching in the youth labour market, wages in unionised labour markets, hours of work, work sharing, matched employee-employer data, education gender gaps, and inter-regional migration. His current interests focus on the methodology and use of linked employeremployee datasets and applying modern instrumental variables techniques to the analysis of health outcomes data.

e-mail: Martyn.andrews@manchester.ac.uk

Lutz Bellmann is head of both the IAB Establishment Panel Project and the IAB Department for Establishments and Employment. Since 2009 he has also been Professor of Labour Economics at the FriedrichAlexander-University Erlangen-Nuremberg. Prof. Bellmann has published in international journals such as Industrial Relations, Journal of Applied Social Science Studies and The British Journal of Industrial Relations.

His current research interests include econometric studies in labour economics, especially employment, apprenticeship training, further training, industrial relations and linked employer-employee panels. $\mathrm{He}$ has been interested in the financial participation of employees since 1989 when he received a scholarship from the Council of Europe. e-mail: lutz.bellmann@iab.de

Thorsten Schank has been a researcher at the University of ErlangenNürnberg since 2002. He obtained an M.A. in Economics at the University of Manchester in 1995 and a Diploma at the University of Heidelberg in 1997. He completed his PhD at the University of Manchester between 1997 and 2001. Between 2001 and 2002, he was a researcher at the Institute of Employment Research, Nürnberg.

His research interests are in applied labour economics. His recent work includes papers on employer-employee data, labour mobility, determinants of wage differentials and labour market effects of foreign firms.

e-mail: thorsten.schank@wiso.uni-erlangen.de

Richard Upward is an Associate Professor of Economics in the School of Economics, University of Nottingham. He received his PhD in economics from the University of Manchester in 1998.

His research interests are primarily in applied labour economics, applied micro-econometrics and the effects of globalisation on the labour market. His recent work includes papers on the costs of worker displacement, linked employer-employee data, search and matching and labour mobility. He has published in journals such as Journal of Human Resources, Oxford Bulletin of Economics and Statistics, Labour Economics, Oxford Review of Economic Policy, Economica and The Journal of the Royal Statistical Society.

e-mail: richard.upward@ nottingham.ac.uk 